\title{
研究农村饮水安全工程运行管理长效机制建设
}

侯桂兰

新疆新和县水利局

DOI:10.32629/hwr.v4i1.2681

[ 摘 要] 本文主要针对农村饮水安全工程运行管理长效机制建设展开深入研究,结合农村饮水安全工程运行管理中存在的不足之处,如缺少完 善的工程管理制度、工程管理过程不力、缺少更为合理的工程设计规划等, 然后重点提出了几点完善措施, 主要包括完善农村饮水安全工程运行 管理制度、严格检测农村饮水水质、规范管护行为、提高工作人员的专业水平、与其他部门之间保持密切的协作等, 充分彰显出农村饮水安全 工程管理长效机制的应用价值,确保农村饮水高效的安全性和可靠性,保证良好的实施效果。

[关键词]农村; 饮水安全工程; 运行管理; 长效机制

现阶段, 在农村经济发展过程中, 饮水安全工程项目建设是至关重 要的, 城乡一体化建设力度大大增强, 进而使农村安全饮水问题得到了 进一步强化, 有助于农村地区供水质量的提升, 有助于与人们的生活需 求相符。但是在农村饮水安全工程运行管理过程中, 仍然存在着较多不完 善的地方, 因此, 必须要加强长效机制管理建设, 提高人们对农村饮水安全 工程的高度重视, 从而避免农村地区环境污染问题的出现, 并给予农村饮 水安全强有力的保证。

\section{1 农村饮水安全工程运行管理中存在的不足之处}

1. 1 缺少完善的工程管理制度

在诸多农村饮水安全工程中, 缺少完善的运行管理制度, 对其原因进 行分析, 首先, 农村饮水安全工程的建设位置并不集中化, 一定程度上导致 运行管理工作难度性的增加。其次, 集中供水项目的所属权较为模糊, 无法 明确管理工作的主要责任制, 管理系统的科学性和高效性也难以保证。再 次, 诸多农村饮水安全工程中的运行管理人员, 其专业能力有待提升, 专业 化训练严重缺失。最后, 诸多农村用户并没有对水质提出较高的要求, 仍然 对自备的水源过渡重视, 进而加剧了平均用水量和设计水量之间的差异性, 使安全饮用水工程运营成本越来越高。

\section{2工程管理过程不力}

在农村饮水安全工程运行管理中, 很多管理人员的思想认知水平较为 薄弱化, 而且缺少先进的管理哦观念。一些偏远山区对农村安全饮水问题 的重视程度不足, 再加上在缺少先进技术和充足资金的影响下, 很难使农 村水利工程顺利完成。此外, 在建设完成并投入使用的工程项目中, 管理措 施仍然较不完善, 一定程度上对工程长期使用造成了不利的影响。

1. 3 缺少更为合理的工程设计规划

在农村地区, 一些水利单位的技术人才的专业性不足, 加剧了运行管 理的难度性, 不利于安全饮水工程经济效益的提升, 其应用功能也无法发 挥出来。同时, 一些工程在设计规划过程中, 建设周期并不长, 缺少清晰明 确的安全饮水的相关参数, 设计内容较为简化, 工程布局的合理性也有待 提升, 从而不利于农村饮水安全工程运行管理工作的开展 ${ }^{[1]}$ 。此外, 某些地 区的工程设计规划, 与当地实际情况也出现了很大的出入, 不利于工程的 顺利建成, 甚至浪费了一些不必要的资源问题。在部分农村安全饮用水工 程中, 消毒和净化的流程较不完善, 进而威胁着饮水安全。

1.4 工作人员的专业水平较为薄弱化

在农村饮水安全工程运行过程中, 专业队伍建设是至关重要的, 这对 于长效机制建设具有很大的帮助, 给予人才强有力的保证制度。但是在实 际上, 工作人员的专业化水平较低, 一些工作人员由于农村出身, 尚未参与 到专业化培训和训练, 而且在步入工作岗位以后, 缺少完善的考核机制, 考
核结果与工作人员绩效也尚未联系在一起, 进而不利于提高工作人员的工 作积极性和主动性。

\section{2 农村饮水安全工程运行管理长效机制建设的具体建议}

2.1完善农村饮水安全工程运行管理制度

要加强管理制度的构建, 明确权责关系, 并维护好经济效益和社会效 益, 落实好农村饮水安全工程的产权, 并明确划分管理责任。如果饮水安全 工程的投资方, 为国家, 乡镇或县级法人应积极承担起工程运行管理责任。 如果是国家为主的单村饮水工程, 群众应积极承担起工程运行管理责任, 村委会成员应发挥出自身的管理职能, 在为分散式工程的情况下, 收益人 应积极承担管理责任。

此外, 还要将经费保障力度提升上来, 第一, 要结合城乡一体化建设, 加强财政经费投入机制的构建, 投入充足的资金, 各个地区要提高对财政 专项列支的高度重视, 进一步落实好农村饮水安全经费。第二, 加强多元化 投资机制的构建, 如果饮水安全工程属于政府出资建设, 应归国家所有, 而 如果为社会资本投资建设, 应属于投资者。第三, 对水价和收费标准进行合 理制定, 各界人士要发挥出监督效力, 避免出现滥用经费问题。

\section{2 严格检测农村饮水水质}

要想不断提高水质质量, 开展管理和维护工作是至关重要的, 在供水 范围内, 加大防范和排污力度, 确保饮水水质的稳步提升。要想将农村饮水 的水质情况予以明确化, 要加强水质监测机制的构建, 将饮水安全管理力 度提升上来, 为农村安全饮水工程建设提供动力, 将饮水水质检测标准予 以明确化, 专业人员应严格检测其水质。同时, 还要加强与卫生单位之间的 交流和沟通, 与疾病控制中心形成合力, 定期检测水厂水质, 给予数据检测 一定的保证, 并做到相互监督。此外, 针对水质检测人员, 应提高对技术培 训的参与热情, 对优秀的水质检测人员予以优先选择, 发挥出人才的保障 性作用。

例如: 以新疆阿克苏地区为例, 地面水多采用江、河水及水库水。在 季节和降水量的影响下, 极容易影响到江、河水流速及流量, 其浑浊度和细 菌含量较高。所以在农村的饮水消毒方面, 对次氯酸钠发生器予以了广泛 应用, 该设备可以防止产生副产物, 原料简单易购买, 对其工作原理进行分 析, 主要是指将盐与水配制成稀盐水, 经过无隔膜电解, 促使次氯酸钠溶液 的产生, 再加上全自动运行, 可以借助APP远程监控, 避免浪费更多的人力 资源。

2. 3规范管护行为

在农村供水运营管理过程中, 必须要对水价形成机制予以高度重视, 这是工程良性运行的重中之重。农村供水和城市供水的差异性较大, 城市 供水水价, 要结合市场机制确定, 而农村供水水价并不适用于结合市场机 
制加以确定, 这是因为当地群众的收入较低, 缺少良好的承受能力, 而且农 村供水规模较小, 规模效应尚未形成, 运行成本比城市供水高出很多。此外, 对农村供水管网进行分析, 具有管网长和用户分散等特点, 一定程度上加 剧了供水成本。基于此, 如果水价较高, 超出了群众的承受范围, 如果水价 较低, 无法确保工程运行的经费, 不利于充分发挥出工程效益。

例如: 以新疆阿克苏地区为例, 该地区从实际情况出发, 既对群众承 受能力进行分析, 也紧密联系工程运行需求, 将水源和运行成本的差异 性体现出来, 加强不同指导性水价的制定。其中, 在2018年, 阿克苏地区 本次拨付资金 1771 万元, 主要用于部分县区 2019 年农村饮水安全巩固提 升工程。按照中央对地方专项转移支付绩效目标表要求, 此项工程本年度 工程合格率预计达到 $90 \%$ 以上, 年度建设任务量预计完成 $80 \%$ 以上, 下一步 阿克苏地区财政局进一步压实责任, 不断提高管护行为的规范性, 加快预 算执行进度, 加快绩效目标完成进度, 确保工程项目的顺利推进。

2. 4 提高工作人员的专业水平

在诸多农村饮水安全问题中, 运行管理工作人员的专业能力有所欠缺, 因此, 工作人员提高自身的专业能力是至关重要的, 为提高运行管理效力 创造条件, 其中, 要做到以下几点: 首先, 将专业知识培训落实到位, 在农村 饮水安全工程运行管理中, 还要注重严格考核培训结果 ${ }^{[2]}$, 保证其技术水 平可以得到保证。其次, 考核管理制度内容, 管理制度可以有效指导管理人 员的工作, 管理人员要对制度形成正确的思想意识, 为规范工作奠定基础。 最后, 普及教育管理人员, 避免超出法律监督的范围, 降低违法行为的出现 概率。

例如: 以以新疆阿克苏地区为例, 该地区的水行政主管部门和相关业 务部门进行了密切的交流, 共同致力于农村饮水安全工程的技术保障, 定 期开展专业培训工作, 尤其在推广和应用新技术和新工艺等方面, 确保对 供水工程技术予以充分掌握, 进而逐步加强农村饮水工程专业队伍建设。 此外, 借助招标方式, 以此来对专业队伍进行篮选和培养, 其中, 新和县扶 贫开发管理办公室, 全过程监督项目开评标。经评标委员会专家认真评审, 向招标人推荐中标候选人。

2.5 与其他部门之间保持密切的协作
在农村饮水安全工程中, 存在着较多的水质影响因素, 尤其在环境和 土壤等方面, 要想确保农村饮水水质的稳步提升, 必须要加强与其他部 门之间的交流和协作, 形成合力作用, 确保饮水安全工程运行管理水平 的稳步提升。其中, 通过与环保部门之间的协作, 可以防止水源污染问题 的出现, 通过与土壤检测部门的协作, 可以对水井中水源含有的微生物 情况进行充分了解, 为采取相应的处理技术带来便利性, 通过与公共卫 生部门的合作 ${ }^{[3]}$, 可以不断优化和改进农村整体面貌, 并对水源中排放污 染物的数量进行控制。结合农村饮水安全保障规划, 各个相关部门对自身 的管理职能予以了正确的思想认知, 不仅明确分工, 而且加大合作和沟通 力度, 在建设新农村的基础设施中, 涵盖了农村饮水工程, 以此来将农村饮 水工程的长期效益发挥出来。总之, 农村饮水安全工程运行管理工作, 与其 他部门之间的协作, 可以避免水体污染行为的出现, 并促进农村饮水安全 工程后续工程的顺利开展。

\section{3 结束语}

综上所述, 在农村饮水安全工程运行管理过程中, 加强长效机制建设 尤为关键, 其中, 要将完善农村饮水安全工程运行管理制度、严格检测农村 饮水水质、规范管护行为、提高工作人员的专业水平、与其他部门之间保 持密切的协作等措施落实到位, 使饮水的安全性得到保障, 维护好农村人 口的生命财产安全, 避免安全隐患的出现, 并进一步践行城乡一体化建设, 确保农村建设的经济效益、社会效益以及生态效益得以保证。

\section{[参考文献]}

[1]贺小强.农村饮水安全工程运行管理存在的问题及对策——以延 川县为例 [J].乡村科技,2019,(28):120-121.

[2]卢书超,马国印,李斌.黄土高原沟餐区农村饮水安全工作的难点与 措施一一甘肃省环县为例[J].中国水利,2019,(13):54-55+64.

[3]李建华.山区农村安全饮水工程建设管理存在的主要问题及解决 对策研究 [J].工程技术研究,2019,4(13):158-159.

作者简介：

侯桂兰(1980--), 女, 青海省乐都县人, 汉族, 大专, 工程师, 研究方 向: 水利工程; 从事工作: 水利运行管理。 